\title{
Stem cells for myocardial repair
}

Chung-Wah Siu'1,2; Song-Yan Liao"; Yuan Liu'; Qizhou Lian¹,2; Hung-Fat Tse ${ }^{1,2}$

${ }^{1}$ Cardiology Division, Department of Medicine, Department of Medicine, Queen Mary Hospital, The University of Hong Kong, Hong Kong, China; ${ }^{2}$ Research Center of Heart, Brain, Hormone and Healthy Aging, University of Hong Kong, Hong Kong, China

\section{Summary}

There is a growing interest in the clinical application for stem cell as a novel therapy for treatment of acute myocardial infarction and chronic myocardial ischaemia. The initial premise is the transplanted exogenous stem cells can engraft and integrate with host myocardium for cardiac regeneration. However, recent experimental studies suggest that multiple mechanisms, including remodelling of extracellular matrix, enhancement of neovascularisation and recruitment of endogenous stem cells are more likely to contribute to the beneficial effects of stem cell therapy that direct trans-differentiation of stem cells into functional myocardium. Among different potential cell sources, bone marrow-derived cells and skeletal myoblasts have been tested in pilot clinical trials. Phase I/II randomised controlled clinical trials suggest that intracoronary or intramyocardial injection of bone marrow-derived cells

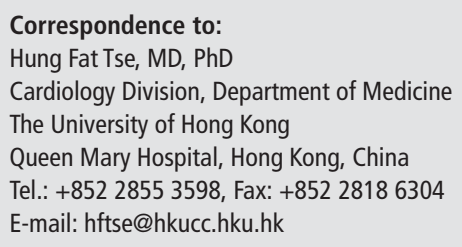

may be safe and feasible strategies for treatment of acute myocardial infarction as well as chronic myocardial ischaemia. In addition, these studies show a modest, but significant improvement in left ventricular ejection fraction and clinical status of patients after cell transplantation. Nevertheless, most of these studies included a relatively small sample size $(<200)$ and short duration of follow-up ( $<6$ months), and the clinical efficacy of stem cell therapy need to be confirmed by future clinical trials. Furthermore, the optimal timing, cell types and mode of delivery need to be addressed, and strategies to improve cell survival and engraftment should also be developed to overcome the potential hurdles related to cell-based therapy.

\section{Keywords}

Stem cells, cardiology, ischaemic heart disease

\section{Financial support:}

This work was supported by grants the Hong Kong Research Grant Council General Research Fund (HKU 763306M, HKU 7747/08M to C.W.S. and H.F.T.) and the CC Wong Stem Cell Fund (to H.F.T.).

Received: May 30, 2009

Accepted after minor revision: July 9, 2009

Prepublished online: March 29, 2010

doi:10.1160/TH09-05-0336

Thromb Haemost 2010; 104: 6-12

\section{Introduction}

Coronary artery disease (CAD) remains the major cause of morbidity and mortality worldwide (1). Despite recent advances in reperfusion therapy for acute myocardial infarction (MI) and pharmacotherapy for post-MI left ventricular (LV) remodelling, the incidence and mortality of post-MI heart failure are increasing (2). There is still major unmet need for treatment of post-MI heart failure due to progressive LV remodelling after initial insult to the myocardium. In patients with end-stage heart failure, the only available curative therapy is heart transplant which is limited by shortage of organs. As a result, there is tremendous interest in developing novel therapies for postMI LV remodelling and dysfunction. In the last few years, stem cell therapies have been investigated as potential treatment for patients with acute MI and chronic myocardial ischaemia.

\section{Mechanisms of action}

The initial premise of cell-based therapy relies on the belief that exogenous cells or mobilised endogenous cells can transdifferentiate into mature cardiomyocytes (CMs) and integrates both electrically and mechanically with host CMs to improvement of cardiac function (3). Clinical evidence demonstrated that new endogenous or exogenous cells can incorporate into host myocardium via trans-differentiation and/or cell fusion (4). However, emerging data have demonstrated that cellular mediated paracrine effects are likely the major mechanism for the improvement in LV function. Our recent experimental studies (5) and others (6) have shown that the transplanted cells can secrete pro-angiogenic cytokines to enhance neovascularisation. The paracrine factors secreted from the transplanted cells exert anti-apoptotic effects, alter the restoration of extracellular matrix and recruit endogenous stem cells (7). Furthermore, there is very limited direct trans-differentiation and long-term survival of transplanted cells $(8,9)$. Indeed, direct injection of cellular extract can provide a similar beneficial effects on cardiac function as intact cell therapy (10).

\section{Different types of cell sources}

Different types of stem or progenitor cells have been investigated for cardiac repair including skeletal myoblast, bone marrow (BM)- 
derived cells, placental/cord blood-derived cells, adipose tissue-derived cells, resident cardiac progenitor cells, embryonic stem cells (ESC) and recently induced pluripotent stem cells (iPSC).

\section{Skeletal myoblasts}

Skeletal myoblasts are skeletal muscle precursor cells which can be isolated from skeletal muscle biopsies and expanded ex vivo to the quantities sufficient for autologous transplantation (11). Experimental studies have demonstrated that transplanted skeletal myoblasts engraft and differentiate into myotubules after transplantation, and improve cardiac function in animal model of MI (12). However, the major concern of skeletal myoblast is the lack of connexin-43 expression after in vitro differentiation and results in the failure of electrical integration with the host myocardium to cause proarrhythmias (13). Indeed, ventricular tachyarrhythmias were observed after skeletal myoblast transplantation in the early clinical trials and remains a potential safety issue (11).

\section{Bone marrow (BM)-derived cells}

BM-derived cells are heterogeneous cellular population consist of $\sim 98 \%$ differentiated cells (haematopoietic cells, vascular cells, adipocytes, osteoblasts and osteoclasts) and $\sim 2 \%$ stem or progenitor cells (haematopoietic stem cells, endothelial progenitor cells [EPC] and mesenchymal stem cells [MSC]). BM-derived stem or progenitor cells have been shown to be able to trans-differentiate into various cell types of the body including neurons, hepatocytes, skeletal muscles and CMs. Similar to skeletal myoblast, BM cells can be readily harvested and expanded ex vivo for autologous transplantation without any immune rejection. Experimental studies suggested that transplantation of BM-derived cells into the acute or chronic ischaemic myocardium resulted in in vivo myogenesis and neo-angiogenesis, and improvement in cardiac function $(5,16)$. As discussed above, the paracrine effects of BM-derived EPC and MSC have been postulated as the major mechanism for the improvement of cardiac function after transplantation $(6,7)$. The encouraging results from pre-clinical studies with different types of BM-derived cells (including mononuclear cells, MSC and EPC) resulted in a series of pilot clinical trials investigating the potential therapeutic use of BM-derived cells in CAD patients. Currently, there is very limited data on the direct comparison of the safety and efficacy between these different types of BM-derived cell for therapeutic use.

\section{Other sources of adult stem cells}

EPC cells can also be mobilised from the BM into the peripheral circulation with haematopoietic growth factors and then collected with an apheresis system for therapeutic use $(14,15)$. EPCs are characterised by their expression of surface markers, such as CD34 and CD 133. Indeed, these surface antigens are used clinically for the isolation of EPC from BM or peripheral blood for therapeutic use. Although isolation of the EPC from peripheral blood is less invasive than direct $\mathrm{BM}$ cell harvesting, the number of EPC obtained from the peripheral blood is lower, and is associated with the cost and potential side effects related to the use of growth factors.

Adipose tissue is another potential source of stem / or progenitor cells, including MSC and EPC for cardiac regeneration. Similar to BM-derived MCSs, adipose tissue derived MSCs have also been shown to differentiate into CM lineage and endothelial lineage, and engraft into host myocardium to improve cardiac function $(17,18)$.

Placental or cord blood is also a rich source of stem cells, including haematopoietic stem cells, MSC and unrestricted somatic stem cells (19). They have a high proliferative potential as compared to similar cell types derived from adult BM. These cells can be easily obtained and cryopreserved after birth for future autologous transplantation.

The presence of resident cardiac stem cells in adult mammalian heart has recently been confirmed (20). Resident cardiac stem cells can be identified by the expression of c-kit and sca- 1 as well as their phenotype and ability to differentiate into functional CMs in culture $(21,22)$. Clinically, resident cardiac stem cells can be obtained from surgical and endomyocardial biopsy, and expanded ex vivo for autologous transplantation. In experimental models of MI, transplantation or mobilisation of resident cardiac stem cells can engraft and acquire cardiac and vascular phenotypes in infarcted myocardium to improve cardiac perfusion and function (22).

\section{Embryonic stem cells (ESC)}

As compared with adult stem cells, ESC can be cultured indefinitely (self-renew) in an undifferentiated state without karyotypic alteration. Furthermore, functional CMs with cardiac-specific structural and functional properties can be consistently differentiated from ESCs with various methods (23). Therefore, ESCs have been considered as potential unlimited ex vivo cell source for cardiac repair. Experimental studies have demonstrated that transplantation of undifferentiated ESCs or their cardiac derivatives into infarcted myocardium can consistently improved LV function post-MI (24). Nevertheless, the current efficiency of in vitro cardiac differentiation from ESC remains low (typically less than 1\%), and a heterogeneous population of CMs (pacemakers, atrial, and ventricular cells) with immature phenotypes are obtained. Together with the potential risk of immune rejection and tumour formation, these issues limited the clinical application of ESC for cardiac regeneration (25).

\section{Induced pluripotent stem cells (iPSC)}

Recent breakthrough in the generation of human iPSC has attached much attention due to it potential implication on tissue re- 
generation (26). These iPSCs generated from the reprogramming process using a combination of transcription factors (Oct $3 / 4$, Sox2, Klf4 and c-Myc), exhibits essential features of ESCs including morphology, surface markers, gene expression profiles and telomerase activity. Experimentally, functional CMs could be differentiated from iPSCs and showed typical features resembling of those from ESC-derived CMs (27). One of the potential advantages of iPSCs over ESC is patient-specific stem cells can be obtained for autologous transplantation to avoid the ethical and immunological issues related to ESC. However, iPSCs still share some of the issues associated with ESC, including the low yield as well as the immature and heterogenous phenotypes with cardiac differentiation. Furthermore, the use of viral vectors to create iPSCs may lead to uncontrolled cellular proliferation, oncogenesis or abnormal development (28).

\section{Mode of cell delivery}

Optimal stem cell therapy depends on successful delivery, engraftment and survival of the transplanted cell. The homing and engraftment of stem or progenitor cells after administration relies on the method of cell delivery, the characteristics of transplanted cells, and the host environment (29). In addition to direct cell delivery, mobilisation of endogenous stem cell can be achieved by administration of cytokines or growth factors. Table 1 summarises the potential application as well as advantage and disadvantage of different methods of cell delivery.

In general, stem cells can be delivered by intravenous or intracoronary routes after coronary revascularisation in the setting of acute MI. The intravenous infusion is easy available, but have a low efficacy for cellular engraftment $(<1 \%)$ due to the cell trapping in the other organs. Selective intracoronary cell injection using the over-the wire infusion balloon catheter allows direct delivery of cell to the infarcted region. However, both intravenous and intracoronary routes are not applicable for patients with an occluded artery and not suitable for delivery of stem cells of larger size or limited migration ability, such as skeletal myoblasts due to risk of microembolisation.

For patients with chronic myocardial ischaemia not amenable to coronary revascularisation, direct intramyocardial injection via either surgical epicardial or transcatheter endocardial approaches due to low level of expression of homing signal for stem cells. Epicardial injection allows direct visualisation of the targeted regions but is only applicable to patients require coronary artery bypass grafting. On the other hand, catheter-based endocardial injection can be performed as stand-alone procedure, but requires the use of special designed injection catheter with or without the use of three dimensional electromechanical mapping systems to guide the injection into the targeted regions. These techniques allow direct cell delivery into the targeted regions even in patients with occluded artery and with the use of certain larger cell types.

In patients with post-MI heart failure due to large area of infarcted and non-viable myocardium, direct injection of stem cells

Table 1: Advantages and disadvantage of potential clinical strategies for stem cell delivery.

\begin{tabular}{|c|c|c|c|c|}
\hline Strategies & $\begin{array}{l}\text { Potential clinical } \\
\text { applications }\end{array}$ & $\begin{array}{l}\text { Clinical } \\
\text { experience }\end{array}$ & Advantage & Disadvantage \\
\hline Intravenous & Acute MI & $+/-$ & $\begin{array}{l}\text { - Easy available and avoid the risk of any } \\
\text { invasive procedure }\end{array}$ & $\begin{array}{l}\text { - Low efficacy of cell delivery } \\
\text { - No applicable to patients with an occluded } \\
\text { artery } \\
\text { - Risk of systemic administration unclear }\end{array}$ \\
\hline Intracoronary & $\begin{array}{l}\text { Acute MI } \\
\text { Chronic MI }\end{array}$ & $\begin{array}{l}+++ \\
+\end{array}$ & $\begin{array}{l}\text { - Possible wide use in catheterisation } \\
\text { laboratory } \\
\text { - Limited risk of systemic administration } \\
\text { - Clinical trials ongoing }\end{array}$ & $\begin{array}{l}\text { - Efficacy of cell delivery to the myocardium } \\
\text { uncertain } \\
\text { - No applicable to patients with a occluded } \\
\text { artery } \\
\text { - No applicable for stem cell with large cells }\end{array}$ \\
\hline $\begin{array}{l}\text { Catheter-based } \\
\text { direct intramyocardial } \\
\text { injection }\end{array}$ & $\begin{array}{l}\text { Chronic myocardial } \\
\text { ischaemia } \\
\text { Acute MI }\end{array}$ & $\begin{array}{l}+++ \\
+\end{array}$ & $\begin{array}{l}\text { - Avoid the risk of open heart surgery } \\
\text { - Higher efficacy of cell delivery } \\
\text { - Short-term safety proven } \\
\text { - Clinical trials ongoing }\end{array}$ & $\begin{array}{l}\text { Need for specialised catheters and imaging } \\
\text { technology to guide the procedure }\end{array}$ \\
\hline $\begin{array}{l}\text { Open heart direct } \\
\text { epicardial injection }\end{array}$ & $\begin{array}{l}\text { Chronic myocardial } \\
\text { ischaemia } \\
\text { Chronic MI }\end{array}$ & $\begin{array}{l}++ \\
++\end{array}$ & $\begin{array}{l}\text { - Applicable to patients who need open } \\
\text { heart surgery } \\
\text { - Allow direct visualisation of the site of } \\
\text { injection }\end{array}$ & $\begin{array}{l}\text { - Risk of mortality and morbidity of open } \\
\text { heart surgery }\end{array}$ \\
\hline Direct epicardial patch & Chronic MI & - & $\begin{array}{l}\text { - Applicable to } \\
\text { patients who need open heart surgery } \\
\text { - Avoid uneven distribution of cell in the } \\
\text { myocardium } \\
\text { - Allow direct delivery of a large amount of } \\
\text { cell }\end{array}$ & $\begin{array}{l}\text { - Need tissue engineering to } \\
\text { create cellular patch } \\
\text { - Risk of mortality and morbidity of open } \\
\text { heart surgery }\end{array}$ \\
\hline
\end{tabular}


into myocardium scar will result in low graft survival and differentiation due to the lack of blood supply as well as paracrine supports from adjacent host CMs. Therefore, the use of bioengineering approaches, such as cardiac patches and injectable delivery matrices are needed to improve cell retention, survival and differentiation (30).

\section{Clinical trials}

\section{Acute myocardial infarction (MI)}

In patients with acute MI, several major randomised controlled clinical trials have been reported with the use of intracoronary administration of autologous BM cells in patients who had undergone successful percutaneous coronary intervention of infarcted related artery. As shown in Table 2, these studies yielded mixed results on the effect of intracoronary administration of BM cells (31-39). The conflicting results of these randomised controlled trials may be due to the small patients sample size $(<200)$, their differences in the study population, the dosage, preparation and types of cells, timing of cell transfer, and the methodology of functional assessment. Nevertheless, no major adverse effect was observed in all these clinical trials. Several meta-analyses have also been reported on the safety and efficacy of intracoronary BM cell therapy during acute MI (40-43). Consistently, all these analysis demonstrated a modest $(\sim 3-4 \%)$ but significant improvement in LV ejection fraction and a small reduction in infarct scar size and LV dimension after intracoronary stem cell therapy as compared with controls. This improvement in LV ejection fraction was similar to those $(\sim 2.5 \%)$ observed in the REPAIR-AMI (Remodelling in Acute Myocardial Infarction) trial which is the largest randomised, controlled clinical study reported (36). Indeed, these magnitude of benefits on LV function observed in stem cell therapy are compatible to those other established therapies for acute MI, such as reperfusion therapies, angiotensin-converting enzyme inhibitors, angiotensin receptor blockers and beta-blockers (44). The clinical efficacy of intracoronary BM cells therapy as well as the optimal timing and dosage of cell administration will be addressed in several larger ongoing trials, such as SWISS-AMI and BOOST-2 trials.

\section{Chronic myocardial ischaemia/ infarction}

In contrast to acute MI, there are only a few small randomised controlled clinical trials on stem cell therapy for treatment of refrac-

Table 2: Randomised controlled trials in acute myocardial infarction.

\begin{tabular}{|c|c|c|c|c|c|c|c|c|}
\hline & No. of patients & $\begin{array}{l}\text { Cell types } \\
\& \text { numbers } \\
\left(x 10^{6}\right)\end{array}$ & $\begin{array}{l}\text { Time to } \\
\text { therapy } \\
\text { (days) }\end{array}$ & $\begin{array}{l}\text { Follow-up } \\
\text { duration } \\
\text { (months) }\end{array}$ & $\begin{array}{l}\text { Primary } \\
\text { endpoint }\end{array}$ & LVEF (\%) & $\begin{array}{l}\text { Infarct } \\
\text { size }\end{array}$ & $\begin{array}{l}\text { Side } \\
\text { effects }\end{array}$ \\
\hline $\begin{array}{l}\text { BOOST } \\
(31,32)\end{array}$ & 30 vs. 30 controls & $\begin{array}{l}2460 \text { BMC with } \\
\text { gelatine-polysucci- } \\
\text { nate density } \\
\text { gradient }\left(9.5 \mathrm{CD} 4^{+}\right)\end{array}$ & 4.8 & 18 & $\begin{array}{l}\text { LVEF (MRI), } \\
\text { safety }\end{array}$ & $\begin{array}{l}6 \text { months: }+6.7 \% \text { vs. } \\
+0.7 \%(\uparrow 6 \%) \\
18 \text { months: }+5.9 \% \text { vs. } \\
+3.1 \% \text { (NS) }\end{array}$ & NS & Nil \\
\hline $\begin{array}{l}\text { Jannsens et al. } \\
\text { (33) }\end{array}$ & 33 vs. 34 controls & $\begin{array}{l}304 \text { BMC with } \\
\text { Ficoll }\left(2.8 \mathrm{CD} 34^{+}\right)\end{array}$ & 1 & 4 & LVEF (MRI) & $+3.4 \%$ vs. $+2.2 \%$ (NS) & $\downarrow$ & Nil \\
\hline $\begin{array}{l}\text { ASTAMI } \\
\text { (34) }\end{array}$ & 50 vs. 50 controls & $\begin{array}{l}68 \text { BMC with } \\
\text { Lymphoprep Ficoll } \\
\left(0.7 \mathrm{CD}^{+} 4^{+}\right)\end{array}$ & 6 & 6 & $\begin{array}{l}\text { LVEF, infarct } \\
\text { size (MRI/ } \\
\text { SPECT/Echo) }\end{array}$ & $+1.2 \%$ vs. $+4.3 \%$ (NS) & NS & Nil \\
\hline $\begin{array}{l}\text { MAGIC CELL-3-DES } \\
\text { (35) }\end{array}$ & 25 vs. 25 controls & $\begin{array}{l}1500 \text { G-CSF mobiliz- } \\
\text { ed PBC }\left(7 \times 10^{6}\right. \\
\text { CD34 })\end{array}$ & 4 & 6 & LVEF (MRI) & $+5.5 \%$ vs. $0 \%(\uparrow 5.5 \%)$ & $\downarrow$ & Nil \\
\hline $\begin{array}{l}\text { REPAIR-AMI } \\
\text { (36) }\end{array}$ & 95 vs. 92 controls & $\begin{array}{l}236 \mathrm{BMC} \text { with Ficoll } \\
\left(3.6 \mathrm{CD} 34^{+}\right)\end{array}$ & 4.4 & 12 & $\begin{array}{l}\text { LVEF (LV angi- } \\
\text { ography) }\end{array}$ & $5.5 \%$ vs. $+3.0 \%(\uparrow 2.5 \%)$ & NS & Nil \\
\hline $\begin{array}{l}\text { Meluzin et al. } \\
\text { (37) }\end{array}$ & $\begin{array}{l}44 \text { (high \& low) vs. } \\
22 \text { controls }\end{array}$ & $\begin{array}{l}\text { High: } 100 \text { BMC } \\
\text { Low: } 10 \text { BMC }\end{array}$ & 7 & 3 & LVEF (SPECT) & $\begin{array}{l}\text { High: }+5 \% \text {; Low: }+3 \% \text {; } \\
\text { Control:+ } 2 \% \\
(\uparrow 2.0 \%)\end{array}$ & NS & Nil \\
\hline $\begin{array}{l}\text { REGENT } \\
(38)\end{array}$ & $\begin{array}{l}117 \text { (selected \& } \\
\text { unselected) vs. } 20 \\
\text { controls }\end{array}$ & $\begin{array}{l}\text { Unselected: } 178 \\
\text { BMC } \\
\text { Selected: } 1.9 \\
\text { CD34/CXCR4 }^{+}\end{array}$ & 7 & 6 & LVEF (MRI) & $\begin{array}{l}\text { Unselected: }+3 \% \\
\text { Selected: }+3 \% \\
\text { Control: } 0 \% \text { (NS) }\end{array}$ & NA & Nil \\
\hline $\begin{array}{l}\text { FINCELL } \\
\text { (39) }\end{array}$ & 40 vs. 40 controls & $402 \mathrm{BMC}$ & $2-6$ & 12 & LVEF (ECHO) & $+7.1 \%$ vs. $+1.2 \%$ & NA & Nil \\
\hline
\end{tabular}


Table 3: Randomised controlled trials in chronic myocardial ischaemia.

\begin{tabular}{|c|c|c|c|c|c|c|}
\hline & No. of patients & $\begin{array}{l}\text { Cell types } \\
\& \text { numbers }\left(x 10^{6}\right)\end{array}$ & $\begin{array}{l}\text { Follow-up } \\
\text { duration } \\
\text { (mths) }\end{array}$ & $\begin{array}{l}\text { Primary } \\
\text { endpoints }\end{array}$ & Secondary endpoints & $\begin{array}{l}\text { Side } \\
\text { effects }\end{array}$ \\
\hline $\begin{array}{l}\text { Losordo et al. } \\
\text { (46) }\end{array}$ & 18 vs. 6 controls & $\begin{array}{l}0.05-0.5 \text { per } \mathrm{kg} \mathrm{G}-\mathrm{CSF} \\
\text { mobilised PBC }\end{array}$ & 6 & $\begin{array}{l}\text { Anginal frequency: } \\
-12.6 \text { vs. }-4.5 \\
\text { ( } \downarrow 8.1, N S) \\
\text { Safety: NS }\end{array}$ & $\begin{array}{l}\text { SPECT perfusion score: }-1.5 \text { vs. }-2.2 \text { (NS) } \\
\text { Exercise time: }+0.5 \text { vs. }+0.3 \text { mins (NS) }\end{array}$ & Nil \\
\hline $\begin{array}{l}\text { PROTECT-CAD } \\
\text { (47) }\end{array}$ & 19 vs. 9 controls & $\begin{array}{l}42 \mathrm{BMC} \text { with Ficoll } \\
\left(1.38 \mathrm{CD}^{+} 4^{+}\right)\end{array}$ & 6 & $\begin{array}{l}\text { Exercise time: } \\
\uparrow 53 \%\end{array}$ & $\begin{array}{l}\text { LVEF (MRI): }+3.7 \% \text { vs. }-0.4 \%(\uparrow 5.4 \%) \\
\text { SPECT perfusion score: }-0.5 \text { vs. }+2.4 \\
(\downarrow 2.7, \text { NS) }\end{array}$ & Nil \\
\hline $\begin{array}{l}\text { Van Ramshorst et al. } \\
\text { (48) }\end{array}$ & 25 vs. 25 controls & 98 BMC with Ficoll & 6 & $\begin{array}{l}\text { SPECT perfusion } \\
\text { score: }-3.4 \text { vs. }-1.1 \\
(\downarrow 2.44)\end{array}$ & $\begin{array}{l}\text { LVEF (MRI): }+3 \% \text { vs. }-1 \%(\uparrow 3 \%) \\
\text { Exercise capacity: }+9 W \text { vs. }+2 W(\uparrow 7 W)\end{array}$ & Nil \\
\hline
\end{tabular}

tory angina due to chronic myocardial ischaemia or heart failure after MI.

For treatment of refractory angina, clinical trials are mainly focused on the use of intramyocardial injections of BM cells as guided by catheter-based three-dimensional electromechancial mapping (45) into chronic ischaemic myocardium which are not amenable to conventional coronary revascularisation (Table 3). Losordo et al. (46) demonstrated intramyocardial injection of granulocyte colony-stimulating factor mobilising $\mathrm{CD}_{4} 4^{+}$cells improved angina frequency and exercise capacity without any change in SPECT perfusion. In contrast, our recent studies (PROTECTCAD) (47) and van Ramshorst et al. (48) have shown that intramyocardial injection of BM mononuclear cells was associated with significant improvement in exercise capacity and clinical status $(47,48)$. As determined by cardiac magnetic resonance imaging, patients received BM cell therapy also showed a modest but significant improvement in $\operatorname{LVEF}(3-5 \%)(47,48)$. Although no overall improvement in SPECT perfusion was observed in the study by Losordo et al. (46) and PROTECT-CAD trial (47), van Ramshorst et al. (48) demonstrated a significant improvement in SPECT perfusion after BM cell injection. The reasons for the conflicting results on SPECT remain unclear, but may be related to the differences in the dosage of cell, study sample size and method of SPECT analysis. More importantly, no significant adverse event, including cardiac arrhythmias was observed after direct intramyocardial injection of BM cells (46-48). Nevertheless, patients with significant

Table 4: Randomised controlled trials in congestive heart failure.

\begin{tabular}{|c|c|c|c|c|c|c|c|}
\hline & No. of patients & $\begin{array}{l}\text { Cell types \& } \\
\text { numbers }\left(x 10^{6}\right)\end{array}$ & $\begin{array}{l}\text { Follow-up } \\
\text { duration } \\
\text { (months) }\end{array}$ & $\begin{array}{l}\text { Primary } \\
\text { endpoint }\end{array}$ & LVEF (\%) & LV dimension & $\begin{array}{l}\text { Side } \\
\text { effects }\end{array}$ \\
\hline $\begin{array}{l}\text { TOPCARE-CHD } \\
(49)\end{array}$ & $\begin{array}{l}24 \text { (PBC), } 24 \text { (BMC) } \\
\text { vs. } 23 \text { (controls) }\end{array}$ & $\begin{array}{l}\text { Intracoronary } \\
\text { injection: } \\
22 \mathrm{PBC} \text { or } 205 \mathrm{BMC} \\
\text { with Ficoll }\end{array}$ & 3 & LVEF (LV angiogram) & $\begin{array}{l}\text { PBC: }-0.4 \% \text {; BMC: } \\
+2.9 \% \text {; Control: } \\
-1.2 \%\end{array}$ & $\begin{array}{l}\text { LV EDV- } \\
\text { PBC: -3\%; BMC: } \\
0 \% \text {; Control: } \\
-3 \% \text { (NS) } \\
\text { LV ESV- } \\
\text { PBC: -2\%; BMC: } \\
+2 \% \text {; Control: } \\
-1 \% \text { (NS) }\end{array}$ & Nil \\
\hline $\begin{array}{l}\text { MAGIC } \\
(50)\end{array}$ & $\begin{array}{l}63 \text { (high and low } \\
\text { dose) vs. } 34 \text { controls }\end{array}$ & $\begin{array}{l}\text { Epicardial } \\
\text { injection: } \\
400 \text { skeletal myo- } \\
\text { blast (low dose); } \\
800 \text { skeletal myo- } \\
\text { blast (high dose) }\end{array}$ & 6 & $\begin{array}{l}\text { LVEF and changes in } \\
\text { number of } \\
\text { akinetic segments } \\
\text { (Echo) }\end{array}$ & $\begin{array}{l}\text { High dose: }+5.2 \% \\
\text { Low dose: }+3.4 \% \\
\text { Control: }+4.4 \% \\
\text { (NS) }\end{array}$ & $\begin{array}{l}\text { LV EDV (ml/m)- } \\
\text { High:-12.6 } \\
\text { Low:-3.9 } \\
\text { Control:+5.9 } \\
(\downarrow 12.8) \\
\text { LV EDV (ml/m)- } \\
\text { High:-8.3 } \\
\text { Low:-6.5 } \\
\text { Control:-2.1 } \\
(\downarrow \text { 8.1) }\end{array}$ & $\begin{array}{l}\text { Non-significant } \\
\text { higher number } \\
\text { of arrhythmic } \\
\text { events in myo- } \\
\text { blast group }\end{array}$ \\
\hline
\end{tabular}


LV dysfunction were excluded in these trials, therefore, the effects of intramyocardial BM cell transplantation in patients with ischaemic LV dysfunction need to address in future clinical trials.

- Table 4 summarises two randomised controlled clinical trials on the use autologous BM or skeletal myoblast in patients with congestive heart failure after MI. In TOPCARE-CHD study, patients with chronic MI (>3 months) were randomised to receive intracoronary transplantation of BM cells or circulating progenitor cells from peripheral blood (49). As compared with controls, patients received intracoronary BM cell transplantation but not circulating progenitor cells showed a modest but significant improvement in LVEF (2.9\%) at three months, but no difference in LV dimension was observed. The use skeletal myoblast has been investigated in patients with ischaemic cardiomyopathy. The Myoblast Autologous Grafting in Ischaemic Cardiomyopathy (MAGIC) trial compared the safety and efficacy of low-dose $\left(400 \times 10^{6}\right)$ or high-dose $\left(800 \times 10^{6}\right)$ autologous skeletal myoblasts versus placebo in patients with ischaemic cardiomyopathy who underwent coronary artery bypass grafting (50). Due to the safety concern of proarrhythmia, all patients were treated with implantable cardioverter-de?brillators before transplantation. Although, there were no significant differences in regional or global LV function, and arrhythmia events between patients treated with skeletal myoblast versus controls, patients treated with higher dose of cells had a significant decrease in LV end-diastolic and end-systolic volume, suggesting the possibility of reverse LV remodelling after stem cell therapy (50).

\section{Future perspectives}

As discussed above, experimental data and pilot human clinical trials suggest that cell-based therapy is a safe and feasible option in patients with CAD. Despite much heterogeneity in different clinical trials, including cell types, dosage, study design, mode of delivery and methodology, there is a modest beneficial effect on the LVEF with the use of intracoronary or intramyocardial BM injection in patients with acute MI or chronic myocardial ischaemia, which beyond the magnitude of conventional therapy with a reasonable safety margin. In addition to define the optimal cell type, dosage and modes of delivery, further refinement of the therapeutic efficacy of cell-based therapy are needed.

First, the use of autologous BM- or MSC-derived cells is confounded by the depletion and/or functional impairment of those stem cells associated with aging, diabetes and severe CAD (51). Furthermore, the cell preparation and selection procedure can also the clinical efficacy of stem cell (52). The use of allogenic cell products with limited immunogenicity, such as MSC derived from different tissues or standardised non-cellular products such as conditional medium or cell extract from different cell source (53) may overcome these problems. Furthermore, in vivo modification such as hypoxic preconditioning or over-expression of angiogenic growth factors before cellular transplantation may also enhance the efficacy of stem cell therapy $(54,55)$.
Second, transplantation of stem cells that can differentiate into functional CMs and integrate with host CMs is required for postMI heart failure due to massive loss of CMs. Among different cell types, resident cardiac stem cell, ESC and iPSCs are potential candidates due to their better potential for proliferation and differentiation into functional CMs. Nevertheless, these cell types also have their own limitation as discussed above. Most importantly, generation of terminally differentiated and homogeneous functional CMs from these different types of stem cells are essential to avoid the issues of teratoma formation and proarrhythmias.

Third, in vitro cell imaging also confirmed the rate of sustained cell engraftment and integration after transplantation remains low (56). Therefore, strategies to enhance cell survival after transplantation is equally important to optimal the therapeutic benefits of stem cells therapy. The low rate of cell engraftment is attributed by the loss of transplanted cells during the cell delivery procedure and the mechanical contraction. Furthermore, multiple mechanisms including ischaemia, inflammatory reaction, apoptosis and loss of cell-cell interactions are likely contribute to the poor survival of transplanted cells. The potential solutions to improve cell engraftment and survival included engineering of transplanted cells to enhance cell homing and in vitro survival $(54,55,57)$, and the use of cardiac patches and injectable delivery matrices (30).

\section{References}

1. Lopez AD, Mathers CD, Ezzati M, et al. Global and regional burden of disease and risk factors, 2001: systematic analysis of population health data. Lancet 2006; 367: $1747-1757$.

2. Velagaleti RS, Pencina MJ, Murabito JM, et al. Long-term trends in the incidence of heart failure after myocardial infarction. Circulation 2008; 118: 2057-2062.

3. Menasche P. Stem cells for clinical use in cardiovascular medicine: current limitations and future perspectives. Thromb Haemost 2005; 94: 697-701.

4. Quaini F, Urbanek K, Beltrami AP, et al. Chimerism of the transplanted heart. N Engl J Med 2002; 346: 5-15.

5. Tse HF, Siu CW, Zhu SG, et al. Paracrine effects of direct intramyocardial implantation of bone marrow derived cells to enhance neovascularization in chronic ischaemic myocardium. Eur J Heart Fail 2007; 9: 747-753.

6. Gnecchi M, Zhang Z, Ni A, et al. Paracrine mechanisms in adult stem cell signaling and therapy. Circ Res 2008; 103: 1204-1219.

7. Fedak PW. Paracrine effects of cell transplantation: modifying ventricular remodeling in the failing heart. Semin Thorac Cardiovasc Surg 2008; 20: 87-93.

8. Balsam LB, Wagers AJ, Christensen JL, et al. Haematopoietic stem cells adopt mature haematopoietic fates in ischaemic myocardium. Nature 2004; 428: 668-673.

9. Murry CE, Soonpaa MH, Reinecke H, et al. Haematopoietic stem cells do not transdifferentiate into cardiac myocytes in myocardial infarcts. Nature 2004; 428 : 664-668.

10. Yeghiazarians Y, Zhang Y, Prasad M, et al. Injection of bone marrow cell extract into infarcted hearts results in functional improvement comparable to intact cell therapy. Mol Ther 2009; 17: 1250-1256.

11. Menasche P, Hagege AA, Vilquin JT, et al. Autologous skeletal myoblast transplantation for severe postinfarction left ventricular dysfunction. J Am Coll Cardiol 2003; 41: 1078-1083.

12. Taylor DA, Atkins BZ, Hungspreugs $\mathrm{P}$, et al. Regenerating functional myocardium: improved performance after skeletal myoblast transplantation. Nat Med 1998; 4: 929-933.

13. Roell W, Lewalter T, Sasse P, et al. Engraftment of connexin 43-expressing cells prevents post-infarct arrhythmia. Nature 2007; 450: 819-824.

14. Wadhwa M, Thorpe R. Haematopoietic growth factors and their therapeutic use. Thromb Haemost 2008; 99: 863-873. 
15. Huang PP, Yang XF, Li SZ, et al. Randomised comparison of G-CSF-mobilized peripheral blood mononuclear cells versus bone marrow-mononuclear cells for the treatment of patients with lower limb arteriosclerosis obliterans. Thromb Haemost 2007; 98: 1335-1342.

16. Orlic D, Kajstura J, Chimenti S, et al. Bone marrow cells regenerate infarcted myocardium. Nature 2001; 410: 701-705.

17. Planat-Benard V, Silvestre JS, Cousin B, et al. Plasticity of human adipose lineage cells toward endothelial cells: physiological and therapeutic perspectives. Circulation 2004; 109: 656-663.

18. Miyahara Y, Nagaya N, Kataoka M, et al. Monolayered mesenchymal stem cells repair scarred myocardium after myocardial infarction. Nat Med 2006; 12: 459-465.

19. Ghodsizad A, Niehaus M, Kogler G, et al. Transplanted human cord blood-derived unrestricted somatic stem cells improve left-ventricular function and prevent left-ventricular dilation and scar formation after acute myocardial infarction. Heart 2009; 95: 27-35.

20. Bergmann O, Bhardwaj RD, Bernard S, et al. Evidence for cardiomyocyte renewal in humans. Science 2009; 324: 98-102.

21. Beltrami AP, Barlucchi L, Torella D, et al. Adult cardiac stem cells are multipotent and support myocardial regeneration. Cell 2003; 114: 763-776.

22. Kajstura J, Urbanek K, Rota M, et al. Cardiac stem cells and myocardial disease. J Mol Cell Cardiol 2008; 45: 505-513

23. Goh G, Self T, Barbadillo Muñoz MD, et al. Molecular and phenotypic analyses of human embryonic stem cell-derived cardiomyocytes: opportunities and challenges for clinical translation. Thromb Haemost 2005; 94: 728-737.

24. Habib M, Caspi O, Gepstein L. Human embryonic stem cells for cardiomyogenesis. J Mol Cell Cardiol 2008; 45: 462-474.

25. Emanueli C, Lako M, Stojkovic M, et al. In search of the best candidate for regeneration of ischemic tissues: are embryonic/fetal stem cells more advantageous than adult counterparts? Thromb Haemost 2005; 94: 738-749.

26. Takahashi K, Tanabe K, Ohnuki M, et al. Induction of pluripotent stem cells from adult human fibroblasts by defined factors. Cell 2007; 131: 861-872.

27. Mauritz C, Schwanke K, Reppel M, et al. Generation of functional murine cardiac myocytes from induced pluripotent stem cells. Circulation 2008; 118: 507-517.

28. Okita K, Ichisaka T, Yamanaka S. Generation of germline-competent induced pluripotent stem cells. Nature 2007; 448: 313-317.

29. Tse HF, Yiu KH, Lau CP. Bone marrow stem cell therapy for myocardial angiogenesis. Curr Vasc Pharmacol 2007; 5: 103-112.

30. Suuronen EJ, Kuraitis D, Ruel M. Improving cell engraftment with tissue engineering. Semin Thorac Cardiovasc Surg 2008; 20: 110-114.

31. Meyer GP, Wollert KC, Lotz J, et al. Intracoronary bone marrow cell transfer after myocardial infarction: eighteen months' follow-up data from the randomized controlled BOOST (BOne marrOw transfer to enhance ST-elevation infarct regeneration) trial. Circulation 2006; 113: 1287-1294.

32. Wollert KC, Meyer GP, Lotz J, Ringes-Lichtenberg S, et al. Intracoronary autologous bone-marrow cell transfer after myocardial infarction: the BOOST randomised controlled clinical trial. Lancet 2004; 364: 141-148.

33. Janssens S, Dubois C, Bogaert J, et al. Autologous bone marrow-derived stem-cel transfer in patients with ST-segment elevation myocardial infarction: doubleblind, randomised controlled trial. Lancet 2006; 367: 113-121.

34. Lunde K, Solheim S, Aakhus S, et al. Intracoronary injection of mononuclear bone marrow cells in acute myocardial infarction. N Engl J Med 2006; 355: 1199-1209.

35. Kang HJ, Lee HY, Na SH, et al. Differential effect of intracoronary infusion of mobilized peripheral blood stem cells by granulocyte colony-stimulating factor on left ventricular function and remodeling in patients with acute myocardial infarction versus old myocardial infarction: the MAGIC Cell-3-DES randomized, controlled trial. Circulation 2006; 114: I145-151.

36. Schachinger V, Erbs S, Elsasser A, et al. Intracoronary bone marrow-derived progenitor cells in acute myocardial infarction. N Engl J Med 2006; 355: 1210-1221.

37. Meluzin J, Mayer J, Groch L, et al. Autologous transplantation of mononuclear bone marrow cells in patients with acute myocardial infarction: the effect of the dose of transplanted cells on myocardial function. Am Heart J 2006; 152: 975, e979-915.

38. Tendera M, Wojakowski W, Ruzyllo W, et al. for the REGENT Investigators Intracoronary infusion of bone marrow-derived selected CD34+CXCR4+ cells and non-selected mononuclear cells in patients with acute STEMI and reduced left ventricular ejection fraction: results of randomized, multicentre Myocardial Regeneration by Intracoronary Infusion of Selected Population of Stem Cells in Acute Myocardial Infarction (REGENT) Trial. Eur Heart J 2009; 30: 1313-1321..

39. Huikuri HV, Kervinen K, Niemela M, et al. Effects of intracoronary injection of mononuclear bone marrow cells on left ventricular function, arrhythmia risk profile, and restenosis after thrombolytic therapy of acute myocardial infarction. Eur Heart J 2009; 29: 2723-2732.

40. Abdel-Latif A, Bolli R, Tleyjeh IM, et al. Adult bone marrow-derived cells for cardiac repair: a systematic review and meta-analysis. Arch Intern Med 2007; 167: 989-997.

41. Lipinski MJ, Biondi-Zoccai GG, Abbate A, et al. Impact of intracoronary cell therapy on left ventricular function in the setting of acute myocardial infarction: a collaborative systematic review and meta-analysis of controlled clinical trials. J Am Coll Cardiol 2007; 50: 1761-1767.

42. Kang S, Yang YJ, Li CJ, et al. Effects of intracoronary autologous bone marrow cells on left ventricular function in acute myocardial infarction: a systematic review and meta-analysis for randomized controlled trials. Coron Artery Dis 2008; 19 : 327-335.

43. Martin-Rendon E, Brunskill SJ, Hyde CJ, et al. Autologous bone marrow stem cells to treat acute myocardial infarction: a systematic review. Eur Heart J 2008; 29 : 1807-1818.

44. Reffelmann T, Konemann S, Kloner RA. Promise of blood- and bone marrow-derived stem cell transplantation for functional cardiac repair: putting it in perspective with existing therapy. J Am Coll Cardiol 2009; 53: 305-308.

45. Tse HF, Kwong YL, Chan JK, Lo G, Ho CL, Lau CP. Angiogenesis in ischaemic myocardium by intramyocardial autologous bone marrow mononuclear cell implantation. Lancet 2003; 361: 47-49.

46. Losordo DW, Schatz RA, White CJ, et al. Intramyocardial transplantation of autologous CD34+ stem cells for intractable angina: a phase I/IIa double-blind, randomized controlled trial. Circulation 2007; 115: 3165-3172.

47. Tse HF, Thambar S, Kwong YL, et al. Prospective randomized trial of direct endomyocardial implantation of bone marrow cells for treatment of severe coronary artery diseases (PROTECT-CAD trial). Eur Heart J 2007; 28: 2998-3005.

48. van Ramshorst J, Bax JJ, Beeres SL, et al. Intramyocardial bone marrow cell injection for chronic myocardial ischemia: a randomized controlled trial. J Am Med Assoc 2009; 301: 1997-2004.

49. Assmus B, Honold J, Schachinger V, et al. Transcoronary transplantation of progenitor cells after myocardial infarction. N Engl J Med 2006; 355: 1222-1232.

50. Menasché P, Alfieri O, Janssens S, et al. The Myoblast Autologous Grafting in Ischemic Cardiomyopathy (MAGIC) trial: first randomized placebo-controlled study of myoblast transplantation. Circulation 2008; 117: 1189-1200.

51. Egan CG, Caporali F, Huqi AF, et al. Reduced levels of putative endothelial progenitor and CXCR4+ cells in coronary artery disease: Kinetics following percutaneous coronary intervention and asoociation with clinical characteristics. Thromb Haemost. 2009; 101: 1138-1146.

52. Seeger FH, Tonn T, Krzossok N, et al. Cell isolation procedures matter: a comparison of different isolation protocols of bone marrow mononuclear cells used for cell therapy in patients with acute myocardial infarction. Eur Heart J 2007; 28: 766-772.

53. Korf-Klingebiel M, Kempf T, Sauer T, et al. Bone marrow cells are a rich source of growth factors and cytokines: implications for cell therapy trials after myocardial infarction. Eur Heart J 2008; 29: 2851-2858.

54. Ii M, Nishimura H, Iwakura A, Wecker A, et al. Endothelial progenitor cells are rapidly recruited to myocardium and mediate protective effect of ischemic preconditioning via ,imported“ nitric oxide synthase activity. Circulation 2005; 111 : 1114-1120.

55. Pons J, Huang Y, Arakawa-Hoyt J, et al. VEGF improves survival of mesenchymal stem cells in infarcted hearts. Biochem Biophys Res Commun 2008; 376: 419-422.

56. van der Bogt KE, Sheikh AY, Schrepfer S, et al. Comparison of different adult stem cell types for treatment of myocardial ischemia. Circulation 2008; 118: S121-129.

57. Elmadbouh I, Haider H, Jiang S, et al. Ex vivo delivered stromal cell-derived factor-1alpha promotes stem cell homing and induces angiomyogenesis in the infarcted myocardium. J Mol Cell Cardiol 2007; 42: 792-803. 